\title{
Glycerol and Ethanol Oxidation in Alkaline Medium Using $\mathrm{PtCu} / \mathrm{C}$ Electrocatalysts
}

\author{
C.A. Ottoni ${ }^{1}$, C.E.D. Ramos $^{2}$, R.F.B. de Souza ${ }^{3}$, S.G. da Silva ${ }^{2}$, E.V. Spinace ${ }^{2}$ and A.O. Neto ${ }^{2 *}$ \\ ${ }^{1}$ Bioscience Institute, São Paulo State University, 11380-972 São Vicente, SP, Brazil. \\ ${ }^{2}$ Instituto de Pesquisas Energéticas e Nucleares, IPEN/CNEN-SP, Av. Prof. Lineu Prestes, 2242 \\ Cidade Universitária, CEP 05508-900 São Paulo, SP, Brazil. \\ ${ }^{3}$ Department of Chemistry, Federal University of Amazonas, Av. General Rodrigo Octávio, 6200, \\ Coroado I CEP: 69080-900, Manaus, AM. Brazil. \\ *E-mail: aolivei@ipen.br
}

doi: $10.20964 / 2018.02 .58$

Received: 25 June 2017 / Accepted: 13 December 2017 / Published: 28 December 2017

\begin{abstract}
The performance of platinum-copper electrocatalysts synthesized in different ratios (100:0, 90:10, 70:30, 50:50, and 0:100), using a borohydride reduction method for electrochemical oxidation of different fuels, was evaluated in an alkaline direct alcohol fuel cell. X-ray diffraction of $\mathrm{Pt} / \mathrm{C}$ and $\mathrm{PtCu} / \mathrm{C}$ showed a face-centered cubic structure (fcc) of the platinum and its alloys. Transmission electron microscopy analysis allowed us to see a good dispersion of metallic particles with some regions with clusters of nanoparticles, for all the synthesised materials in the presence of copper. Cyclic voltammetry and chronoamperometry tests demonstrated that the $\mathrm{PtCu} / \mathrm{C}(50: 50)$ and $\mathrm{PtCu} / \mathrm{C}$ (70:30) electrocatalysts exhibited the highest activity and stability for the glycerol and ethanol oxidation, respectively. The tests made in fuel cells, directly fed with glycerol and ethanol, presented the $\mathrm{PtCu} / \mathrm{C}$ (90:10) electrocatalyst as the most effective on the oxidation reaction of the fuels when compared with $\mathrm{Pt} / \mathrm{C}$ and $\mathrm{Cu} / \mathrm{C}$.
\end{abstract}

Keywords: Direct ethanol fuel cell, direct glycerol fuel cell, $\mathrm{PtCu}$ electrocatalysts, alkaline fuel cell

\section{FULL TEXT}

(C) 2018 The Authors. Published by ESG (www.electrochemsci.org). This article is an open access article distributed under the terms and conditions of the Creative Commons Attribution license (http://creativecommons.org/licenses/by/4.0/). 